\title{
Influence of Giulio Grablovitz in Spain: instruments and scientific correspondence
}

\author{
Josep Batlló \\ CGUL-IDL, Universidade de Lisboa, Portugal
}

\begin{abstract}
It is known that Giulio Grablovitz founded and operated a «geodynamic» station on Ischia Island from 1885 up to his death. But it is almost unknown that one of the instruments he designed, the horizontal pendulum, was installed at Ebre Observatory in Spain. Records from this instrument and correspondence between Grablovitz and the Ebre observatory are still preserved. These documents show how the research work done by Grablovitz was introduced and diffused in Spain. Also, they give us some new information on the construction of the seismic instruments designed by Grablovitz. The present paper deals with the analysis of the preserved materials, assesses the introduction of Grablovitz research in Spain and shows the importance of the use of manuscript sources for the enhancement of current research in seismology.
\end{abstract}

Key words horizontal pendulums - Giulio Grablovitz, Ebre Observatory - Cartuja Observatory - Spain

\section{Introduction}

Giulio Grablovitz (1846-1928), born in Trieste, was the director of the first Italian «Geodynamic Station» founded in 1885 at Casamicciola, on Ischia island, in the Bay of Naples. His scientific research is mainly remembered for its contributions to seismometry and also to tides and tide gauge studies. He was in touch with other earth scientists of his time and, from his observatory at Ischia, he maintained regular correspondence with many geophysicists.

Of our interest, in the first days of May of the year 1906 a letter from G. Grablovitz was received at Ebre Observatory, sited in the NE

Mailing address: Dr. Josep Batlló, CGUL-IDL, Universidade de Lisboa, Campo Grande, Edifício C8, 1749 016 Lisboa, Portugal; e-mail: jobatllo@fc.ul.pt. part of Spain. It referred the registration of the San Francisco earthquake at this observatory and stated:

«Ischia 26 Aprile 1906 / Ch.mo Collega ed Amico / Ricevo con grande soddisfazione il suo primo bollettino sismico coi dati della registrazione del terremoto di California e sono lieto di vedere che i miei pendoli hanno funzionato a dovere. Ciò significa ch'ella l'ha collocati in tutta regola e [...] faccio $i$ miei complimenti. / Qui pure ho avuto una registraziane analoga...»

«[Ischia, 26 April 1906 / Dear colleague and friend / I've received with a great pleasure your first seismic bulletin with data of the California earthquake and I'm proud to see that my pendulums recorded it properly. This means that they have been installed properly and [...] I present my compliments. / Here we also had a similar record ...]».

This letter, reproduced in fig. 1, and some others preserved as well, shows an already well established relation between Grablovitz and the Ebre observatory, where a copy of the horizontal pendulums already existing at Ischia was installed in 1905. 
These pendulums were the only instrument designed by Grablovitz ever to have been installed outside Italy.

In this sense, the relation of G. Grablovitz with the Ebre Observatory was the most fruitful one of all the scientific contacts he had. Not so much is known about it and only some scarce documents are preserved. But, recently, I found some new letters of the correspondence between Grablovitz and the Ebre Observatory at the Archive of the Jesus Society in Barcelona. This finding allows a reappraisal of this scientific relationship. Consequently, what is known about the relations of G. Grablovitz with Spanish seismologists and his influence on Spanish seismology will be analysed in the following paragraphs. Also, it will be shown how it is possible to use this information to improve current research in seismology.

\section{Italian seismology in Spain}

It is not clear (to me) how Italian seismological theory and practice were introduced in Spain. Nowadays, it is clear that geographical and cultural proximity favored such introduction. Also, the strong influence the Catholic Church exerted in both countries and the close relations existing between members of the religious institutes of both countries at that time were obvious ways of introduction of Italian Earth science theories in Spain.

Due to the lack of further analysis of such relations, this is a topic that should be studied in the future. Nevertheless, it is clear that Italian ideas on seismology had an overwhelming acceptance among Spanish scientists in the last quarter of the 19th century.

An example of this fact is the wide distribution obtained in Spain of the book by M. De Rossi (1879; 1882).

Many of the Spanish scientific libraries already existing at that time still have a copy of it. Another example of this influence is the discourse of D. Cortázar, a mining engineer, on his acceptance as a member of the Academy of Sciences of Madrid in 1884 (Cortázar y Fernández de Castro, 1884). It is devoted to seismology and, in its pages, Cortázar shows a wide and

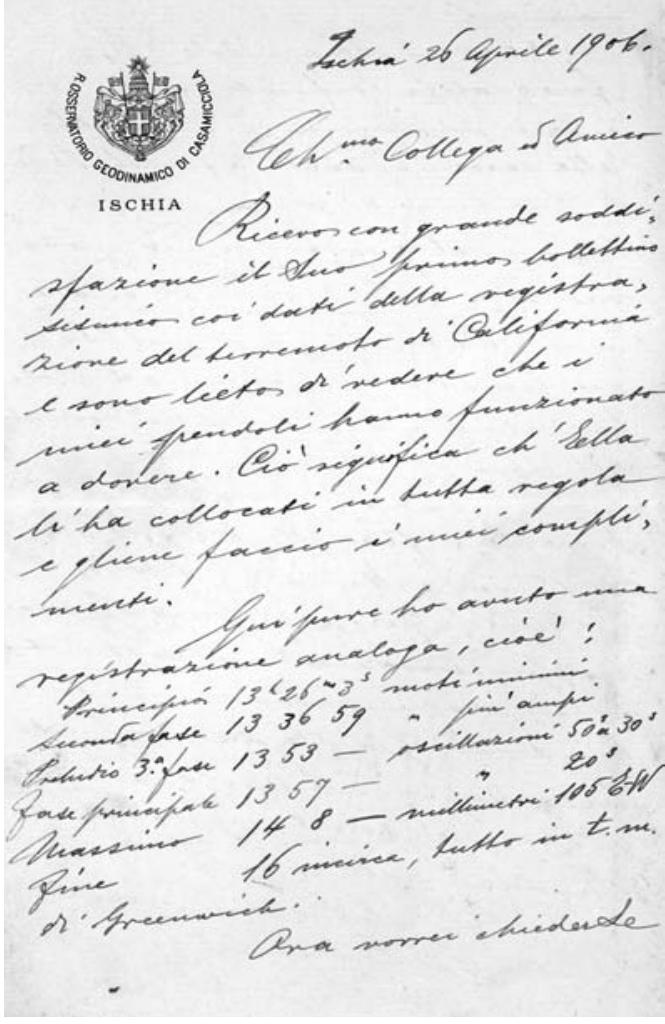

Fig. 1. Letter of G. Grablovitz to R. Cirera, director of the Ebre Observatory dated 26 April 1906 (copy of the original letter preserved at the Ebre Observatory Archive).

deep knowledge of Italian seismological practice at that time (it should be noted that Fernández de Castro shows a deep knowledge of the geological work of Stoppani).

Just a few months later, on 25 December 1884 , a great earthquake hit the SE part of Andalucía, in Spain. It was one of the largest earthquakes to have occurred in Europe in the last quarter of the 19th century. At that time, scientists around Europe showed a great interest to study the causes of this earthquake and several commissions were sent to the epicentral area and elaborated detailed reports about it (Fernández de Castro et al., 1885; Tarramelli and 
Table I. List of seismic stations created in Spain at the end of the 19th century and the beginning of the 20th century. They are classified in main stations (those historically cited everywhere - e.g. López Arroyo et al., 1990) and secondary stations (those found in further researches - e.g. Batlló and Bormann, 2000). The second column states the source of the original instruments equipping those stations. The instrumentation of the Tivissa station may be also considered from Italian origin due to its characteristics.

\begin{tabular}{llll}
\hline \hline \multicolumn{3}{c}{ Spanish seismic stations seismograph origin } \\
\hline Main stations & & Secondary stations \\
\hline San Fernando (1887) & English & Madrid (1887) & Italian \\
Cartuja (1902) & Italian & Puerto Orotava (1889) & German \\
Ebre (1904) & Italian & Olot (1907) & Italian \\
Fabra (1906) & Italian & Girona (1908) & Italian \\
Toledo (1909) & Mixed & Riotinto (1909) & English \\
Almería (1911) & Italian - German & Tivissa (1910) & Self made \\
Málaga (1913) & Italian - German & & \\
Alicante (1914) & Italian - German & & \\
\hline
\end{tabular}

Mercalli, 1885; Fouque, 1886). After this large earthquake in Andalucía, several scientists in Spain asked for a network of «geodynamic» observatories. A new, the use of the term «geodynamic» is a clear indication of the Italian influence (e.g. de Castro Pulido, 1895).

It is clear that the overwhelming influence of Italian seismology in Spain expanded at least until the first decade of the 20th century.

This influence can be seen just taking a look at the seismic instrumentation installed in the Spanish Observatories (for a more detailed information on the type and characteristics of the instruments installed in Spanish observatories see Batlló and Bormann, 2000, or Batlló, 2004). Table I shows the origin of the seismological instrumentation at the different Spanish observatories at the turn of the 20th century. As can be seen, Italian instruments were installed in the majority of observatories.

In addition, the number of instruments account for almost two thirds parts of the seismic instruments installed in Spain in those early years.

\section{The Ebre Observatory and G. Grablovitz}

Ebre observatory was founded in 1904 and its main objective was the study of the relation between geophysical and solar activity (now known as solar-terrestrial physics). To fulfil this aims, a complete set of astronomic and geophysical instruments were installed (Cirera, 1905). Among them, a seismic station was set up (Batlló and Ugalde, 2000; Ugalde, 2003).

Two different types of seismographs were chosen to complete the instrumental set of this station: a Vicentini microseismograph for horizontal and vertical motion record and a couple of Grablovitz horizontal pendulums. It is not known why or how the Grablovitz horizontal pendulums were chosen. What it is known is that the Jesuit R. Cirera (1864-1932), the first director of the Ebre observatory, devoted several years before the foundation of this observatory to a scientific journey through different European observatories with the goal to study the state of the art of the different fields of interest (solar studies, geomagnetic field, meteorology, 


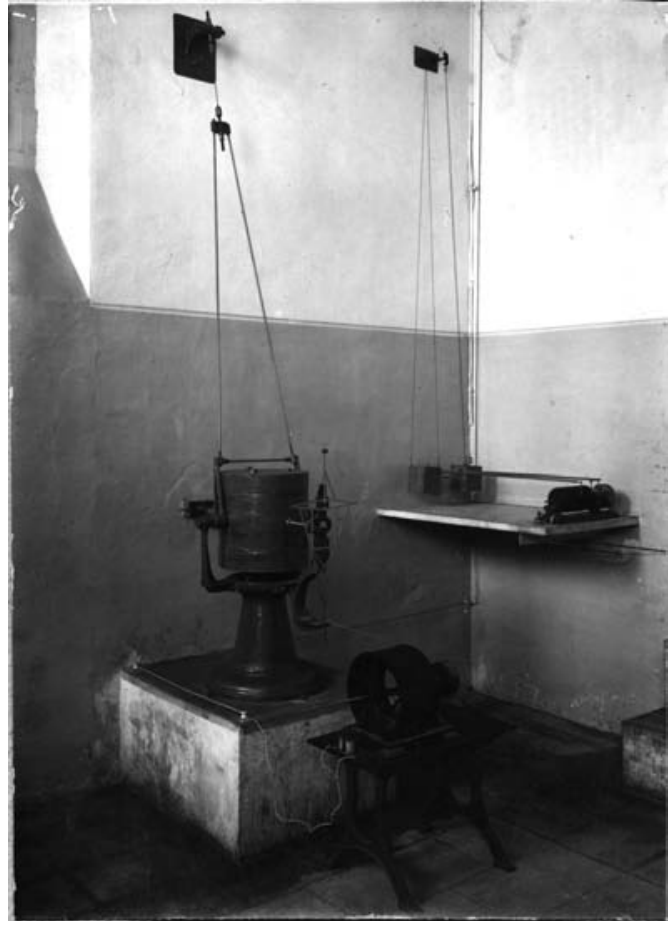

Fig. 2. The Grablovitz pendulums (right) installed at the seismic pavilion of the Ebre Observatory (circa 1915). The larger seismograph in the center of the photograph is the Mainka-Ebre instrument, constructed at the Ebre Observatory (copy of the original photograph preserved at the Ebre Observatory Archive).

seismology, ...) for the new observatory. It can be assumed that he established contact with G. Grablovitz travelling in Italy. It is not clear if he contacted Grablovitz directly because he was aware of his scientific career or he did so after the advice of some colleague. The second option is the most likely.

It should be noted that the seismic section of the Ebre Observatory was, from the first, and in spite of its intrinsic quality, a secondary part of the main project of the Ebre observatory. This means that, to set it up, the chosen instrumentation was selected to be enough to fulfil the desired objectives, but not very expensive or cumbersome to operate. This can be the main rea- son for the choice of a Vicentini microseismograph and the Grablovitz pendulums. It is known that the Vicentini microseismograph was a good instrument for recording regional seismicity. The last instrument was able to record teleseismic events and, both together, fulfilled the requirements in this field for the planned station.

The Grablovitz instrument was operative at Ebre observatory from 1905 to 1918. Around one thousand records of this seismograph are still preserved. The usefulness of these records for current seismological studies has been shown by different authors (Abe 1994; Dineva et al., 2002; Stich et al., 2003). From 1910 to 1913, a regular monthly bulletin was published presenting the results of the observations and even some copies of the obtained records. Those bulletins are the only printed information known about this instrument. Also, a unique photograph of the instrument installed at Ebre is preserved (fig. 2). It is interesting to note that the official records of the observatory state that operation of the Grablovitz pendulums was discontinued in 1913, when a large reconstruction of the seismic pavilion was undertaken. However, preserved seismic records from this instrument show clearly that it was operative up to 1918. Also, the preserved photograph of the instrument is dated between 1915 and 1916, when the new Mainka type instruments, also visible in the photograph, were installed. This photograph (fig. 2) shows the instrument in its latest installation, fixed against the wall of the seismic pavilion. Previously, it was fixed at a brick column in the centre of the pavilion. Figure 3 shows a sketch of the seismic pavilion with the original location of the Grablovitz instrument, fixed against a brick column.

Fortunately, to complete our knowledge of the operational life of the Grablovitz pendulums in Spain, some letters and manuscript documents forming part of the correspondence between G. Grablovitz and the Ebre Observatory have been preserved. Some of them are still kept at the archive of the Observatory (e.g. the letter about the San Francisco earthquake reproduced in fig. 1) and another group have been recently discovered and are located at the Archive of the Catalan Province of the Jesus Society in 


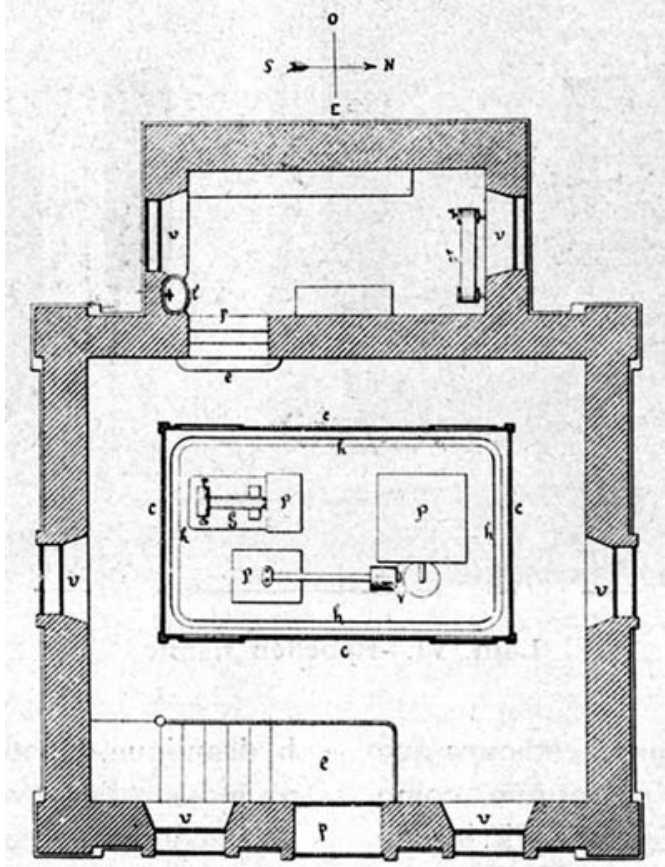

Fig. 3.-Croquis de la instalación sísmica

V. Sismógrafo Vicentini.-G. Sismógrafo Grablovitz.-P. Pilares para el sostén de los sismógrafos.c. Vitrina. - h. Hendidura. $-p$, v. Puertas y ventanas.-e. Escaleras.-1. Lavabo.-r. Aparato para el ahumado y exámen de las gráficas del Vicentini.

Fig. 3. Sketch of the seismic pavilion of the Ebre Observatory (from Pericas, 1910).

Barcelona. It will be shown that these materials are of real importance to understand how the Grablovitz pendulums operate.

The first preserved letter dates from 18 March 1904. It states that the pendulums built for the Ebre Observatory are ready and tested and «lui sono riuscite assai più sensibili di quelli che già erano in azione» (they are much more sensitive that those already installed [in Ischia]). Also, it asks to Cirera, the director of Ebre Observatory if he wants to install a time marking system. It should be recalled at this point that Grablovitz had a deep interest in time accuracy in the seismic records. In this aspect he was really far beyond most of his contempo-

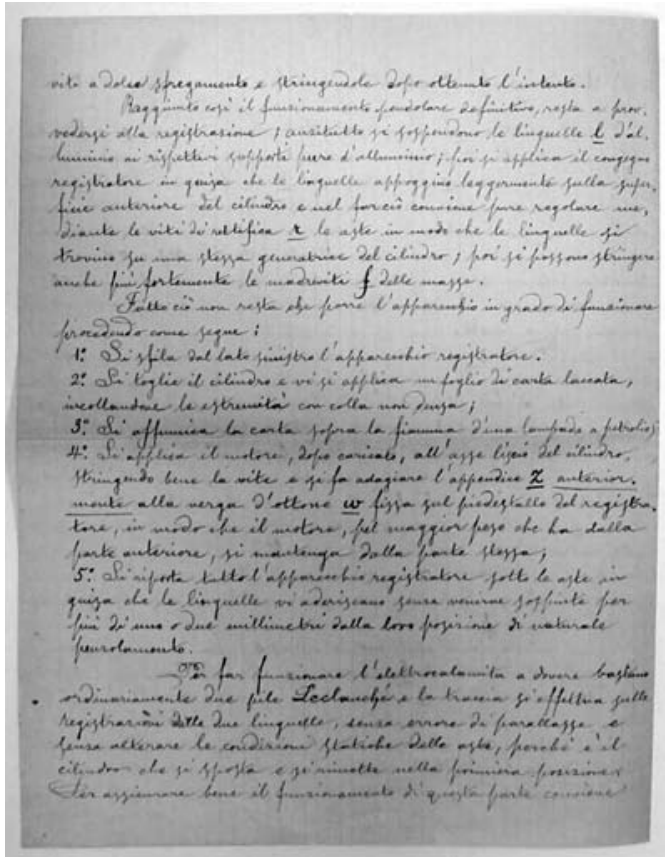

Fig. 4. Second page of the instructions to install the Grablovitz horizontal pendulums sent by Grablovitz to the Ebre Observatory (copy of the original documents preserved at the Archive of the Jesus Society in Barcelona).

raries. Looking at the contents of this letter, it should be likely that some previous correspondence exists; but it has never been found. Another possibility is that Cirera ordered the Grablovitz instrument «in person» and this was the first letter between both scientists. This is one of the multiple questions without answer due to the lack of further information.

The analysis of the preserved documents shows that the most important ones, from a seismological point of view, are two sheets of paper written on both sides containing the instructions for the installation of the new instrument (fig. 4). There, it is accurately described how to set up the oscillating masses or the inscription mechanism, with special care to the proper setting of the stylus. Those instructions were translated carefully into Spanish at the Ebre observatory (they are also preserved), and 

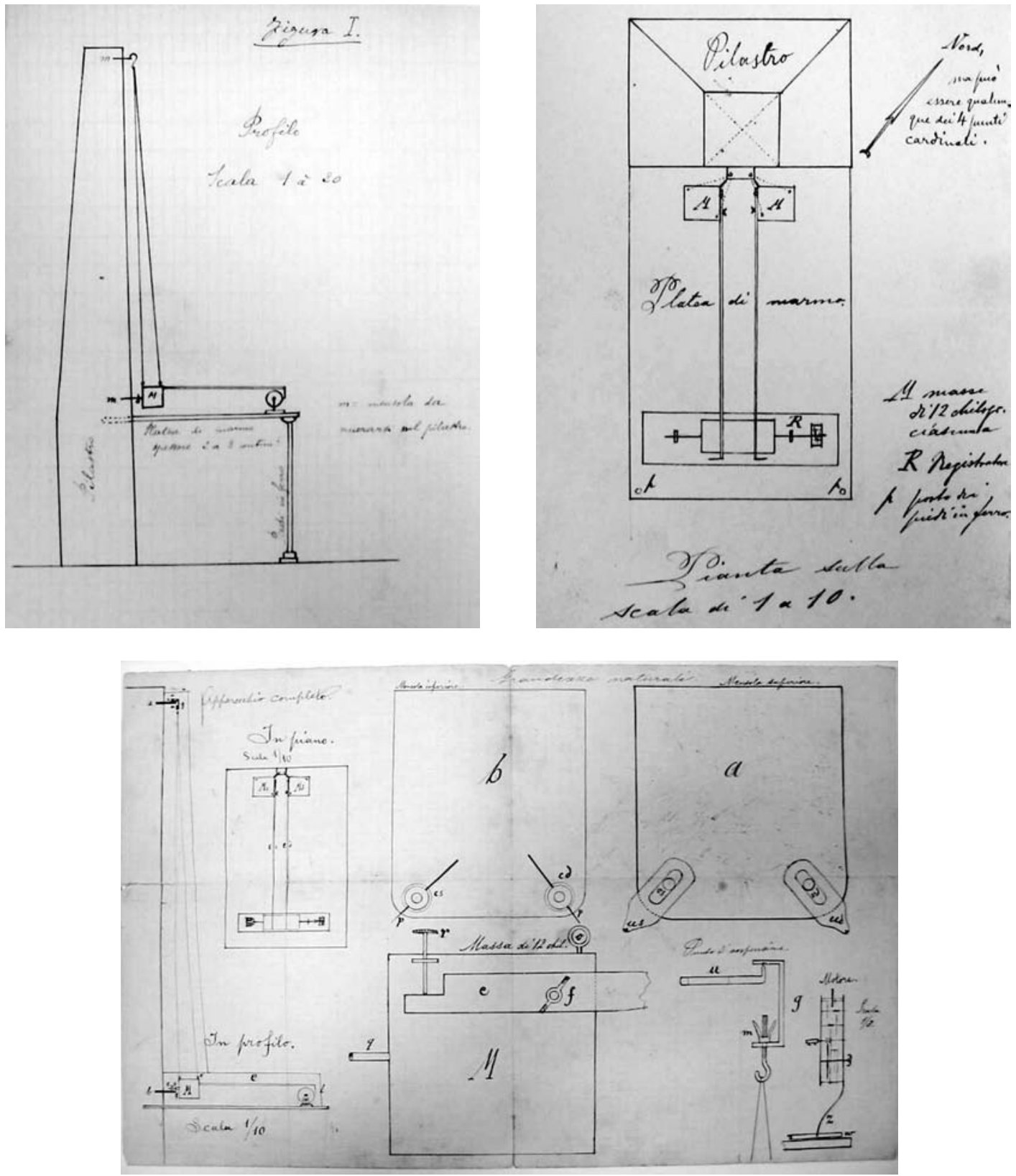

Fig. 5 a-c. Sketches of how to install the Grablovitz horizontal pendulums. a) lateral view showing the column and table sustaining the oscillating masses; b) top view showing the long stylus; c) details of the masses and related elements (copies of the original documents preserved at the Archive of the Jesus Society in Barcelona). 
are the unique existing instructions for such kind of seismograph preserved. As the instruments installed at Ischia stations (both, Porto d'Ischia and Casamicciola) were operated by Grablovitz himself, it is quite normal that he never wrote any detailed instructions for its installation and use. This gives extra importance to the found document. Also, some sketches of how to install the instrument (fig. 5), and even some drawings of the lower and upper fixations at $1: 1$ scale are preserved.

These documents show how important the study of manuscript documents can be. Looking at the currently preserved documents and pieces, the addition of the original pieces of the Grablovitz horizontal pendulums preserved at Ischia, the existing photographs of these instruments at Ischia and Ebre, and the recently found manuscript documents will be enough, if needed, to allow for a complete reconstruction of an operative version of the seismograph, the found instructions allowing for a fine and easy «tuning» of the instrument.

To end this section, it should be noted that the Ebre observatory instrument was not the only interest of Grablovitz in Spain. In the same letter of 26 April 1906, Grablovitz asks Cirera for the possibilities to find some convenient place near the Ebre Observatory or in Mallorca island to perform tide measurements, another of his topics of interest. As far as it is known, no further development was reached in this line.

\section{The diffusion of the Grablovitz pendu- lums in Spain}

As has been stated, the Grablovitz horizontal pendulums installed at Ebre Observatory were the unique instrument of this type operating in Spain, but the interest in this instrument spread further than the Ebre Observatory. Since 1906 Manuel M. Sánchez-Navarro Neumann (1867-1941) had been the director of the Cartuja seismological observatory, in Granada (Espinar, 2002). Sánchez-Navarro and the Cartuja Observatory were deeply interested in the study and construction of efficient seismographs. One of the strongest points of the research developed at Cartuja observatory was a consequence of this special interest in the seismic instrumentation. This topic will not be developed here (see Batlló, 2002), but it should be stated that, after a careful study of the existing models, the observatory of Granada developed their own instruments based on almost all the main construction principles for seismographs (SánchezNavarro, 1927). As a result, it was considered, for many years, the best seismic station in Spain (Rey-Pastor, 1932).

Of our interest within a ten year period, Sánchez-Navarro wrote, two long reviews about the different models of seismographs utilised worldwide (1907-1908; 1919-1920). It is extremely interesting to note he devoted some lines to the description of the Grablovitz horizontal pendulums in both reviews. In the first one of them (1907-1908) - later translated into French in an abridged version (1909) -, Sánchez-Navarro, in just one page, describes carefully the main characteristics of the instrument. In addition, he states that he had the opportunity to inspect the model installed at the Ebre Observatory. In addition, as a curiosity for us, he states the price of this instrument: 90 lire at that moment.

In the second review (1919-1920), SánchezNavarro goes further. He devoted one and a half pages to a more detailed description of the instrument that in the previous review and he finished the general description with the following paragraph (translated from Spanish):

«The circumstance that there is no important constructor of seismographs involved in the construction of this instrument, so simple, so easy to use and even cheap, has definitely been of great importance for the small diffusion of them because, if [the instrument is] improved with independent recording cylinders for each component with, at least, a speed of $60 \mathrm{~cm} / \mathrm{hour}$, damping and a improved stylus they may be really useful in those places where earth shakes heavily and frequently, and the main periods of the macroseisms are quite low, as happens in the Pacific coast of South America and the Philippine Islands».

As can be seen, he is stating, in very few and concise words, the necessary improvements to update the instrument. It is noteworthy that this was written in the year 1919 and, still at that time, even a quarter of a century after their 
first design, Sánchez-Navarro was considering it a good instrument for seismic recording. Unfortunately, despite the close contacts, and even the direct influence that the Cartuja Observatory exerted on some South American seismic stations, nobody took in consideration these suggestions and the Grablovitz pendulums did not expand on South America or Philippines.

\section{Remarks and conclusions}

As has been seen, the research on seismic instrumentation done by G. Grablovitz had continuity in Spain. His horizontal pendulums were installed at Ebre observatory and SánchezNavarro, from Cartuja Observatory, showed a great interest in this instrument.

Ebre observatory keeps around one thousand records of its Grablovitz horizontal pendulums and other printed and manuscript documents from this seismograph. Some of these records have been recently digitized and used for the analysis of large earthquakes in Europe with success. A careful analysis of the preserved documents at Ebre observatory shows some discrepancies between the official and the real existence of this instrument.

The addition of the printed documents, manuscript documents and surviving parts of the instrument at Ischia and Ebre are enough to afford the reconstruction of the Grablovitz horizontal pendulums. Such reconstruction should give us a deeper knowledge of the special characteristics of the records obtained with this instrument. This will improve the results of future analysis of old earthquakes recorded with the horizontal pendulums.

In addition, the interest of Grablovitz to expand his tidal observations to other places around the Mediterranean Sea has been confirmed.

\section{Acknowledgments}

This research was started by the author at Ebre Observatory. It has been partly supported by the projects BHA2001-1393, REN20012418-C04-01 and REN2002-11055-E / RIES of the Dirección General de Investigación (DGI) of the Spanish Ministry of Science and Technology. The archive of the Province of Catalonia of the Jesus Society, and especially its director J. Roca, is acknowledged for the facilities he offered to investigate and reproduce the documents of the Ebre Observatory preserved on its files.

\section{REFERENCES}

ABE, K. (1994), Instrumental Magnitudes of Historical Earthquakes, 1892 to 1898, Bull. Seism. Soc. Am., 84, 415-425.

BATLLó, J. and A. UGalde (2000): Els sismògrafs de l'Observatori de l'Ebre., in Actes de la V Trobada d'Història de la Ciència i de la Técnica, edited by J. BATLló et al. (Institut d'Estudis Catalans, Barcelona), pp. 161-165.

BATLló, J (2004): Catálogo - Inventario de Sismógrafos Antiguos Españoles, (Instituto Geográfico Nacional, Madrid), pp. 414.

BAtlló, J and P. BoRmann (2000): A catalog of old Spanish Seismographs, Seismological Research Letters, 71, 570-582.

Batlló, J (2002): Los Sismógrafos del Observatorio de Cartuja, in Historia del Observatorio de Cartuja 19022002. Nuevas investigaciones. CD-ROM, edited by M. EsPINAR, J.A. Esquivel and J.A. PEÑA, (Instituto Andaluz de Geofísica, Universidad de Granada).

Cirera, R. (1905): Notice sur l'Observatoire et sur quelques observations de l'éclipse du 30 Août 1905, (Mémoires de l'Observatoire de l'Ebre, no. 1, Barcelona, Gustavo Gili).

Cortázar, D. y M. Fernández de CASTRo (1884): Discursos leídos ante la Real Academia de Ciencias Exactas, Físicas y Naturales en la recepción pública del Sr. D. Daniel de Cortázar, (Real Academia de Ciencias Exactas, Físicas y Naturales, Madrid), pp. 113.

De Castro Pulido, J. (1895): Conveniencia de establecer una red de observatorios sísmicos en España, La Naturaleza, 6, 92-95 and 102-105.

DE Rossi, M.S. (1879): La meteorologia endogena, vol. I., (Fratelli Dumolard, Milano).

De Rossi, M.S. (1882): La meteorologia endogena, vol. II., (Fratelli Dumolard, Milano).

Dineva, S., J. Batlló, D. Mihailov and T. Van Eek (2002): Source parameters of four strong earthquakes in Bulgaria and Portugal at the beginning of the 20th century, Journal of Seismology, 6, 99-123.

EsPINAR, M. (2002): Notas sobre la vida y obra del R.P. Manuel, M. Sánchez-Navarro S.J. Neumann (18671941), in Historia del Observatorio de Cartuja 19022002. Nuevas investigaciones. CD-ROM, edited by M. EsPinAR, J.A. Esquivel and J.A. PeÑA, (Instituto Andaluz de Geofísica, Universidad de Granada, Granada).

Fernández de CASTRo, M., J.P. Lasala, D. CoRTÁZAR y J. Gonzalo TARín (1885): Terremoto de Andalucía: Informe de la Comisión nombrada para su estudio dando cuenta del estado de los trabajos en 7 de Marzo de 1885, (Imp. de M. Tello, Madrid), pp. 107. 
FOUQUE, F. (1886): Mission d'Andalousie: Etudes relatives au tremblement de terre du 25 décembre 1884 , et à la constitution géologique du sol ébranlé par les secousses, Acad. Sci. Mem., XXXX, 1-772.

López Arroyo, A., J. Cruz, A. Roca and C. Olivera (1990): Early seismographic instruments in Spain, in Gli strumenti Sismici Storici, edited by G. FERRARI (SGA Storia-Geofisica-Ambiente, Bologna), 161-164.

PERICAS, J. (1910): Sismología, Boletin mensual del Observatorio del Ebro (Enero de 1910 con una introducción), I (1), 55-57.

Rey-Pastor, A. (1932): El Servicio Sismológico Español, A Terra, 1, 36-40.

SÁnchez-NAVARRo NeumanN, M.M. (1907): Estudio comparativo de los instrumentos más usados en Sismología, Revista de la Real Academia de Ciencias Exactas, Físicas y Naturales de Madrid, 6, 653-674, 761772, 859-867 and 911-926.

SÁnCHEZ-NAVARRo NeumanN, M.M. (1908): Estudio comparativo de los instrumentos más usados en Sismología, Revista de la Real Academia de Ciencias Exactas, Físicas y Naturales de Madrid, 7, 121-144.

SÁnCHEZ-NAVARro NeumanN, M.M. (1909): Aperçu des instruments plus utilisés en seismologie, Ciel et Terre, XIV, 295-326.
SÁNCHEZ-NAVARRo NEUMANN, M.M. (1919): Ensayo crítico sobre los sísmógrafos más en uso (generalidades y péndulos verticales de registro mecánico), Asociación Española para el Progreso de las Ciencias, Congreso de Sevilla, vol. IV, Section 2a , (Astronomía y Física del Globo), 33-69.

SÁNCHEZ-NAVARRo NEUMANN, M.M. (1920): Ensayo crítico sobre los sísmógrafos más en uso (péndulos horizontales e invertidos de registro mecánico), Asociación Española para el Progreso de las Ciencias, Congreso de Bilbao, vol. IV, Section 2a , (Astronomía y Física del Globo), 51-89.

SÁnChez-NAVARro Neumann, M.M. (1927): Le Séismographes de la Station Séismologique de Cartuja (Granada), Publ. Du Bureau Central Séismologique International, Série A, Travaux Scientifiques, 4, 119-131.

Stich, D., J. Batlló, J. Morales, R. Macià and S. Dineva (2003): Source parameters of the $1910 \mathrm{Mw}=6.1$ Adra earthquake (southern Spain), Geophysical Journal International, 155, 539-546.

Tarramelli, T. and G. Mercalli (1885): I terremoti Andaluci cominciati il 25 decembre 1884, R. Acc. Lincei, CCLXXXIII.

Ugalde, A. (2003): The Ebre Observatory seismological station: past and present instrumentation and noise conditions, Annals of Geophysics, 46, 609-624. 